\title{
Performance of FRP-Jacketed RC Columns under Axial-Flexural Loading
}

\author{
[ Hanan Al-Nimry, Ahmad Soman ]
}

\begin{abstract}
This article presents the results of an experimental investigation of the behavior of circular reinforced concrete columns strengthened with fiber reinforced polymer (FRP) sheets under the combined action of axial loads and bending moments. Test parameters included the absence/presence of FRP jackets, fiber orientation and stiffness of the jacket. Test results proved that the investigated FRP strengthening schemes can be efficiently used to enhance the load-carrying capacity and deformability of eccentrically loadedcolumns. When compared to the FRP hoop confined columns, the inclusion of an axial FRP sheet was found to have negligible effects on the axial column resistance however, the longitudinal fibers increased both the axial and flexural rigidities of the strengthened columns. Using an axial FRP sheet confined by two hoop FRP sheets enhanced the columns' rotational capacities allowing them to absorb eccentric loads with increasing lateral deflections.
\end{abstract}

Keywords-RC columns, axial-flexural loading, confinement, FRP-jacketing, deformation capacity, toughness

\section{Introduction}

Fiber reinforced polymers (FRP) fabrics are commonly used as external hoop confinement to enhance the axial loadcarrying capacity and ductility of deficient reinforced concrete (RC) columns. The design of FRP-confined RC columns has been addressed in a number of international guidelines [e.g. 13].

Unfortunately, most researchers have examined the effect of FRP hoop confinement on axially loaded concrete cylinders and small-scale plain concrete columns (rather than RC columns) neglecting the effects of strain gradient induced by bending moments which are usually encountered in eccentrically-loaded columns. A number of researchers [4-21] have examined the influence of loading eccentricity on the confinement provided by FRP hoops. Their studies have confirmed that the typical hoop FRP confinement can be used to enhance the strength and ductility of columns even under eccentric loading. However, strength enhancements were found to be highly dependent on the controlling mode of failure [22].

The experimental investigation reported herein was devised to provide better insights into the behavior of eccentrically-loaded FRP-confined concrete by testing medium scale circular RC columns. The tests were intended to examine the effects of fiber orientation and stiffness of the external FRP wraps on the axial-flexural behavior of the columns.

Hanan Al-Nimry, Ahamd Soman (Authors)

Civil Engineering Department / Jordan University of Science and Technology Jordan

\section{Experimental Program}

\section{A. Test Specimens}

Eight circular short RC columns were tested under axial compression with an eccentricity of $50 \mathrm{~mm}$. The test specimens (192 $\mathrm{mm}$ in diameter and $1175 \mathrm{~mm}$ in height) were designed as short columns following ACI 318-14 [23] provisions. All columns were reinforced with 6 longitudinal steel deformed rebars of $10-\mathrm{mm}$ diameter. Transverse reinforcement was provided using 6-mm diameter steel ties, with a $60 \mathrm{~mm}$ overlap, at a uniform center-to-center spacing of $125 \mathrm{~mm}$ as shown in Fig. 1.

To examine the effect of fiber orientation and stiffness of the FRP jacket, specimens were grouped into four identical pairs. Two columns were reserved as control unwrapped specimens whereas the remaining 6 columns were fully wrapped using carbon FRP sheets. Three FRP jacketing systems were considered: a) The $1 \mathrm{C}$ columns were wrapped with one hoop CFRP ply with fibers oriented parallel to the column's circumference; b) the L1C columns were wrapped using two plies of the fabric sheets with fibers oriented parallel and perpendicular to the longitudinal column axis in the first and second FRP plies, respectively; and c) the L2C columns were wrapped using three plies of the fabric sheets with fibers oriented parallel to the longitudinal column axis in the first ply and parallel to the hoop direction in the two outer plies. Specimen details are summarized in Table 1.

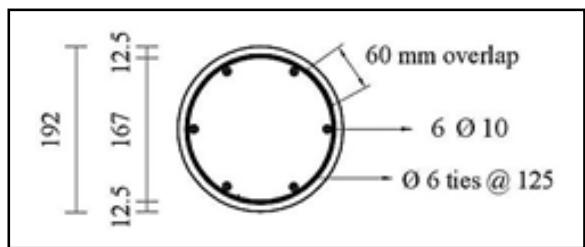

Figure 1. Cross-sectional details of test columns (dimensions and bar diameters are in $\mathrm{mm}$ )

TABLE I. SUMMARY OF TEST SPECIMENS AND PARAMETERS

\begin{tabular}{|c|c|c|c|}
\hline \multirow{3}{*}{$\begin{array}{c}\text { Specimen } \\
\text { Designation }\end{array}$} & \multirow{3}{*}{$\begin{array}{c}\text { No. of } \\
\text { Specimens }\end{array}$} & \multirow{2}{*}{\multicolumn{2}{|c|}{$\begin{array}{c}\text { CFRP Strengthening Scheme } \\
\text { Fiber Orientation and Number } \\
\text { of FRP Plies }\end{array}$}} \\
\hline & & & \\
\hline & & Axial & Ноор \\
\hline $\mathrm{U}$ & 2 & \multicolumn{2}{|c|}{ None } \\
\hline $1 \mathrm{C}$ & 2 & 0 & 1 \\
\hline L1C & 2 & 1 & 1 \\
\hline L2C & 2 & 1 & 2 \\
\hline
\end{tabular}




\section{B. Materials}

The columns were cast using normal weight concrete with an average 28-day compressive strength of $33 \mathrm{MPa}$. At time of column testing, an increase in concrete strength of about $25 \%$ was attained. Compressive testing of concrete cylinders $(150 \times 300 \mathrm{~mm})$ that were cast, wet-cured and tested with their companion column specimens resulted in an average compressive concrete strength of about $41 \mathrm{MPa}$. Average yield strengths of the longitudinal and transverse reinforcing steel were about 450 and $530 \mathrm{MPa}$, respectively.

Unidirectional high strength carbon FRP sheets (MBRACE FIBER CF $230 / 4900.300 \mathrm{~g} / 5.100 \mathrm{~m}$ ) were used for the external column reinforcement. The $500 \mathrm{~mm}$ wide carbon FRP sheets with a nominal thickness of $0.166 \mathrm{~mm}$ had a tensile strength of $4900 \mathrm{MPa}, 2.1 \%$ strain at break and an elastic tensile modulus of $300 \mathrm{GPa}$ (based on manufacturer's data).

\section{Specimen Casting and Strengthening}

Test specimens were cast in a vertical position using PVC plastic molds. Columns were de-molded 24 hours after casting, wet-cured for 28 days and then transferred to the open lab environment. Six specimens were strengthened using the three wrapping schemes described earlier, namely the 1C, L1C and $\mathrm{L} 2 \mathrm{C}$ configurations. For the $\mathrm{L} 1 \mathrm{C}$ and $\mathrm{L} 2 \mathrm{C}$ configurations, fibers of the first ply were oriented parallel to the longitudinal column axis whereas fibers of the second and third plies were oriented parallel to the column's circumference.

Concrete surfaces were cleaned and prepared following BASF instructions. A $100 \mathrm{~mm}$ overlap length along the hoop direction and a $20-\mathrm{mm}$ overlap length in the axial/vertical direction were provided for the circumferential FRP wraps. A 20-mm overlap length was provided along the hoop direction for the longitudinal FRP wraps. To provide for additional confinement at column ends, all specimens were wrapped with an additional 200-mm wide FRP hoop ply.

Figure 2. Test setup (dimensions in $\mathrm{mm}$ )
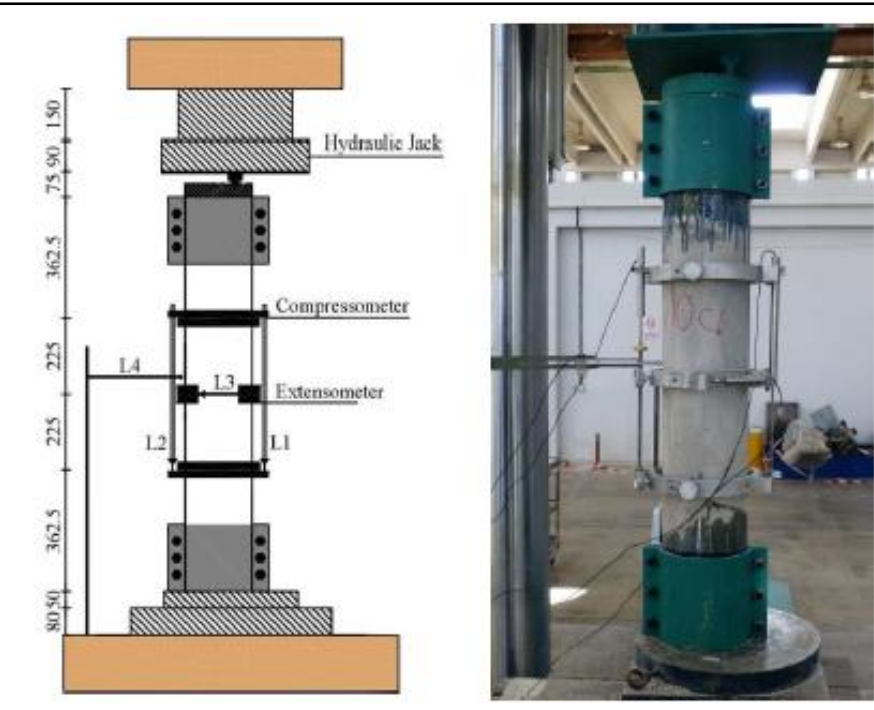

\section{Test Setup and Instrumentation}

All specimens were tested under axial compression at an eccentricity of $50 \mathrm{~mm}$ using a $4000 \mathrm{kN}$ Universal Testing Machine. To prevent premature failure at column ends, 200$\mathrm{mm}$ wide rigid steel collars were fastened at both column ends providing additional confinement at locations of expected stress concentration.

Axial loading was applied using displacement control at a constant rate of $0.3 \mathrm{~mm} /$ minute. Column loading was increased gradually until significant strength degradation was observed marking the state of strength failure.

Using the compressometer-extensometer measurement system shown in Fig. 2, each specimen was instrumented with 3 linear variable displacement transducers (LVDTs). The L1 and L2 transducers were used to measure average axial displacements (over a gage length of $450 \mathrm{~mm}$ ) at both the compression and tension column sides whereas the L3 transducer was mounted onto the extensometer to measure hoop strains at mid-height. An additional transducer (L4) was mounted to measure lateral displacements at column midheight. Load and displacement data were collected using an automatic data acquisition system at a rate of one reading per second.

\section{Test Results}

\section{A. General Response and Failure Modes}

Response parameters presented in Tables II and III are based on the axial force-displacement $(F-\Delta)$ relationships of the relevant specimens shown in Fig. 3 where $F_{\mathrm{u}}$ is the ultimate resistance or axial load-carrying capacity, $\Delta_{\mathrm{u}}$ is the corresponding axial displacement and $\Delta_{\max }$ identifies the displacement corresponding to a point on the $F-\Delta$ curve past ultimate resistance at which axial resistance drops by $20 \%$ indicating strength failure. The initial secant stiffness $\left(\mathrm{K}_{\mathrm{i}}\right)$ represents the slope of a straight line starting from the origin and intersecting the F- $\Delta$ curve at an axial load value of $0.5 F_{\mathrm{u}}$. Toughness values represent the area under the $F-\Delta$ curve up to the ultimate state.

Figure 3. Axial load-displacement relations of test specimens

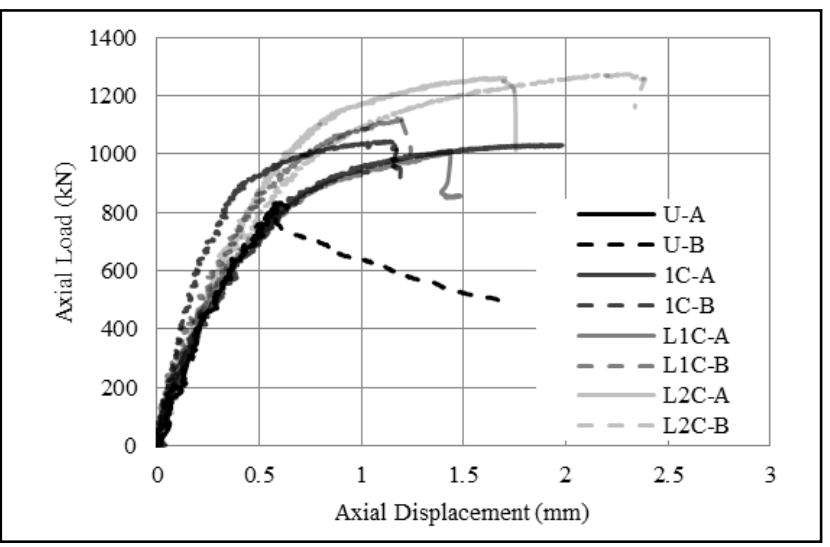


Inspection of strength values in Table II shows an increase in maximum load-carrying capacity of the $1 \mathrm{C}, \mathrm{L} 1 \mathrm{C}$ and $\mathrm{L} 2 \mathrm{C}$ jacketed columns by $27 \%, 30 \%$ and $55 \%$, respectively compared to that of the control columns.

Test results confirmed that axial and hoop strains of the eccentrically-loaded columns increased significantly as a result of FRP reinforcement. Ultimate axial strains of the $1 \mathrm{C}$, L1C and L2C wrapped columns were found to be 2.6, 2.2 and 3.4 times, respectively those of the control columns whereas hoop strains were found to be $4.2,4.7$ and 7.8 times, respectively.

The observed variations in initial stiffness values of the columns can be attributed to the unavoidable variations in concrete strengths of the different concrete batches used to cast the specimens as well as in compaction, curing and FRP strengthening of the columns.

The significant enhancement in column deformability as expressed by toughness of the FRP-wrapped columns (4-7 times that of the control specimens) is associated with the effectiveness of the hoop FRP sheets in bridging the micro cracks in concrete leading to an increased capacity of the whole composite section to absorb energy prior to failure.

Failure of the eccentrically-loaded control columns was signified by concrete crushing in the compression side and tensile concrete cracking (parallel to hoop direction) in the tension side of column. Failure was initiated between the upper most ties located beneath the top steel collar and propagated axially downwards.

Figure 4. Examples of failure patterns of FRP-jacketed columns

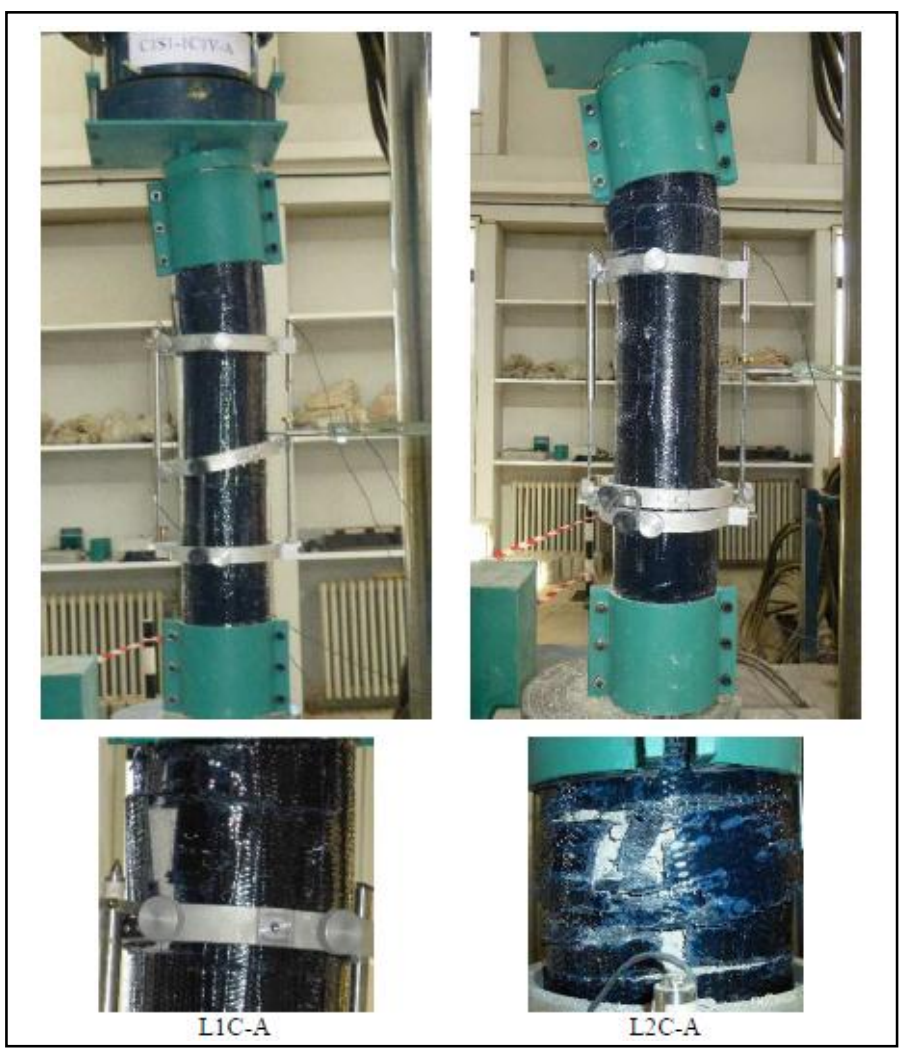

Local buckling of the longitudinal steel bars was noted within the zone of compressed concrete in the control columns and became less obvious as the level of external confinement increased. For FRP-confined columns, the same type of failure resulted in rupturing the hoop FRP sheets in the compression zone and induced tensile cracks in the hoop FRP plies as observed in the tension side of column. Rupture of the longitudinal sheets was only observed in the tension side of columns strengthened with the L2C configuration signifying higher levels of the secondary bending moments. Failure became of a more explosive nature as the level of FRP confinement increased. Buckling was noted in all of the test columns and became more obvious in the $1 \mathrm{C}$ confined columns as compared to the unconfined columns. Examination of the FRP jackets indicated satisfactory lamination between the different FRP layers and bonding between the concrete surface and carbon sheets was excellent. The FRP sheets did not rupture at overlap positions. Fig. 4 shows examples of the observed failure patterns of the FRP-jacketed columns.

\section{B. On the FRP Wrapping Systems}

The three investigated strengthening schemes proved their efficiency in enhancing the load-carrying capacity and deformability of eccentrically-loaded columns.

TABLE II. AXIAL FORCE AND DISPLACEMENTS

\begin{tabular}{|c|c|c|c|c|c|}
\hline \multirow{2}{*}{ Specimen } & \multirow{2}{*}{$\begin{array}{c}F_{\mathbf{u}} \\
(\mathbf{k N})\end{array}$} & \multirow{2}{*}{$\begin{array}{c}K_{\mathrm{i}} \\
(\mathrm{kN} / \mathbf{m m})\end{array}$} & \multicolumn{3}{|c|}{$\begin{array}{c}\text { Axial displacement } \\
(\mathbf{m m})\end{array}$} \\
\hline & & & $\Delta_{u}$ & $\Delta_{\max }$ & $\Delta_{l}$ \\
\hline $\begin{array}{l}\text { U-A } \\
\text { U-B }\end{array}$ & 819 & 1885 & 0.60 & 0.83 & 2.35 \\
\hline $\begin{array}{l}1 \mathrm{C}-\mathrm{A} \\
1 \mathrm{C}-\mathrm{B}\end{array}$ & $\begin{array}{l}1037 \\
(127)^{\mathrm{a}}\end{array}$ & $\begin{array}{l}2389 \\
(127)\end{array}$ & $\begin{array}{l}1.57 \\
(262)\end{array}$ & $\begin{array}{l}1.58 \\
(190)\end{array}$ & $\begin{array}{l}12.53 \\
(533)\end{array}$ \\
\hline $\begin{array}{l}\text { L1C-A } \\
\text { L1C-B }\end{array}$ & $\begin{array}{l}1067 \\
(130)^{\mathrm{a}}\end{array}$ & $\begin{array}{l}2192 \\
(116)\end{array}$ & $\begin{array}{c}1.32 \\
(220)\end{array}$ & $\begin{array}{c}1.36 \\
(164)\end{array}$ & $\begin{array}{l}8.24 \\
(351)\end{array}$ \\
\hline $\begin{array}{l}\text { L2C-A } \\
\text { L2C-B }\end{array}$ & $\begin{array}{c}1268 \\
(155)^{\mathrm{a}}\end{array}$ & $\begin{array}{l}1854 \\
(98)\end{array}$ & $\begin{array}{c}2.01 \\
(335)\end{array}$ & $\begin{array}{c}2.07 \\
(249)\end{array}$ & $\begin{array}{l}15.87 \\
(675)\end{array}$ \\
\hline
\end{tabular}

TABLE III. TOUGHNESS AND STRAIN MEASUREMENTS

\begin{tabular}{|c|c|c|c|}
\hline \multirow{2}{*}{ Specimen } & \multirow{2}{*}{$\begin{array}{c}\text { Toughness } \\
\text { (kN.mm) }\end{array}$} & \multicolumn{2}{|c|}{$\begin{array}{c}\text { Ultimate Strain } \\
\left(\times 10^{-3}\right)\end{array}$} \\
\hline & & Axial & Ноор \\
\hline $\begin{array}{l}\text { U-A } \\
\text { U-B }\end{array}$ & 285 & 1.33 & 0.30 \\
\hline $\begin{array}{l}1 \mathrm{C}-\mathrm{A} \\
1 \mathrm{C}-\mathrm{B}\end{array}$ & $\begin{array}{l}1304 \\
(458)^{\mathrm{a}}\end{array}$ & $\begin{array}{l}3.50 \\
(263)\end{array}$ & $\begin{array}{l}1.26 \\
(420)\end{array}$ \\
\hline $\begin{array}{l}\text { L1C-A } \\
\text { L1C-B }\end{array}$ & $\begin{array}{l}1026 \\
(360)^{\mathrm{a}}\end{array}$ & $\begin{array}{l}2.92 \\
(220)\end{array}$ & $\begin{array}{c}1.41 \\
(470)\end{array}$ \\
\hline $\begin{array}{l}\text { L2C-A } \\
\text { L2C-B }\end{array}$ & $\begin{array}{l}1977 \\
(694)^{\mathrm{a}}\end{array}$ & $\begin{array}{l}4.47 \\
(336)\end{array}$ & $\begin{array}{l}2.34 \\
(780)\end{array}$ \\
\hline
\end{tabular}


Compared to the unwrapped columns, the 3-ply FRP wrapping scheme brought significant improvements in strength amounting up to $60 \%$. In general, the L2C wrapping scheme enhanced the axial, hoop and lateral deformation capacities of the test columns in addition to their axial strength. Compared to the $1 \mathrm{C}$ and $\mathrm{L} 1 \mathrm{C}$ configurations, the added confinement provided by the second hoop FRP sheet enhanced the column's rotational capacity allowing the columns to absorb eccentric loads with increasing lateral deflections.

Using an axial FRP sheet confined by a hoop sheet introduced negligible improvements in the load-carrying capacity of the columns over that already gained by using the 1C confining scheme (an increase of about $3 \%$ ). As a result of the added flexural rigidity, the L1C configuration managed to reduce the lateral displacement (up to 34\%) of the eccentrically-loaded columns while achieving slightly higher strength capacities (up to $3 \%$ ) compared to their companion $1 \mathrm{C}$ confined columns.

\section{Conclusions}

Eight medium scale FRP-jacketed RC columns were tested under the combined effect of axial loading and bending moments. Test results confirmed that unidirectional carbon FRP sheets can be efficiently used to strengthen circular RC columns and enhance their load-carrying capacity and deformability under eccentric loading. FRP wrapping allowed the eccentrically-loaded columns to achieve higher strengths at larger lateral deflections.

Negligible improvements in load-carrying capacity of the columns over that already gained by using the typical hoop confining scheme were noted upon the use of the longitudinal FRP sheet. However, the longitudinal fibers increased both the axial and flexural rigidities of the strengthened columns.

\section{Acknowledgment (Heading 5)}

Experimental work presented in this article was funded by Deanship of Research at Jordan University of Science and Technology under grant No. 2015/334.

\section{References}

[1] fib. Externally bonded FRP reinforcement for RC structures. Bulletin No. 14, Technical Report, Fédération internationale du Béton, Lausanne, Switzerland, 2001.

[2] ACI 440.2R. Guide for the design and construction of externally bonded FRP systems for strengthening concrete structures, American Concrete Institute, Farmington Hills, 2008.

[3] CAN/CSA-S806-12. Design and construction of building structures with fibre-reinforced polymers. Canadian Standards Association, Ontario, Canada, 2012.

[4] C. Jaturapitakkul, K. Kiattikomol, S. Chucheepsakul, and A. Siripanichgorn, "Effect of confinement on reinforced concrete columns subjected to eccentric loading," IABSE Reports, Vol. 81, pp. 78-85, 1999.

[5] O. Chaallal, and M. Shahawy, "Performance of fiber-reinforced polymer-wrapped reinforced concrete column under combined axialflexural loading," ACI Struct. J., Vol. 97, pp. 659-668, 2000.
[6] A. Parvin, and W. Wang, "Behavior of FRP jacketed concrete columns under eccentric loading," Compos. Constr., Vol. 5, pp. 146-152, 2001.

[7] Z. Tao, J.G. Teng, L.H. Han, and L. Lam, "Experimental behaviour of FRP-confined slender RC columns under eccentric loading," In: proceedings of 2nd International Conference on Advanced Polymer Composites for Structural Applications in Construction, Guildford, UK, pp. 203-212, 2004.

[8] R. Sause, K.A. Harries, S.L. Walkup, S. Pessiki, and J.M. Ricles, "Flexural behavior of concrete columns with carbon fiber composite jackets," ACI Struct. J., Vol. 101, pp. 708-716, 2004.

[9] M.N.S. Hadi, "Behaviour of FRP wrapped normal strength concrete columns under eccentric loading," Compos. Struct., Vol. 72, pp. 503511, 2006.

[10] M.N.S. Hadi, "Behaviour of FRP strengthened concrete columns under eccentric compression loading," Compos. Struct., Vol. 77, pp. 92-96, 2007.

[11] M. Ranger, and L. Bisby, "Effects of load eccentricities on circular FRP confined reinforced concrete columns," In: proceedings of 8th International Symposium on Fiber-Reinforced Polymer Reinforcement for Concrete Structures, University of Patras, Greece, 2007.

[12] M.N.S. Hadi, "Behaviour of eccentric loading of FRP confined fibre steel reinforced concrete columns,' Constr. Build. Mater.; Vol. 23, pp. 1102-1108, 2009.

[13] T. El Maaddawy, "Strengthening of eccentrically loaded reinforced concrete columns with fiber-reinforced polymer wrapping system: experimental investigation and analytical modeling," Compos. Constr., Vol. 13, pp. 13-24, 2009.

[14] M. Hadi and V. Yazici, "Axial load-bending moment diagrams of carbon FRP wrapped hollow core reinforced concrete columns," Compos. Constr., Vol. 13, pp. 262-268, 2009.

[15] S. Rocca, N. Galati, and A. Nanni, "Interaction diagram methodology for design of FRP-confined reinforced concrete columns," Constr. Build. Mater., Vol. 23, pp. 1508-1520, 2009.

[16] L.A. Bisby, and M. Ranger, "Axial-flexural interaction in circular FRPconfined reinforced concrete columns," Constr. Build. Mater., Vol. 24, pp. 1672-1681, 2010.

[17] P. Sadeghian, A. Rahai, and M. Ehsani, "Experimental study of rectangular RC columns strengthened with CFRP composites under eccentric loading," Compos. Constr., Vol. 14, pp. 443-450, 2010.

[18] L. Bisby, and M. Ranger, "Axial-flexural interaction in circular FRPconfined reinforced concrete columns" Constr. Build. Mater. Vol. 24, pp. 672-1681, 2010.

[19] B. Csuka, and L. P. Kollár, "Analysis of FRP confined columns under eccentric loading," Compos. Struct., Vol. 94, pp. 1106-1116, 2012.

[20] Y. Wu, and C. Jiang, "Effect of load eccentricity on the stress-strain relationship of FRP-confined concrete columns," Compos. Struct., Vol. 98, pp. 228-241, 2013.

[21] A. Parvin, and D. Brighton, "FRP Composites Strengthening of Concrete Columns under Various Loading Conditions," Polymers, Vol. 6, pp. 1040-1056, 2014.

[22] L. C. Bank, Composites for Construction: Structural Design with FRP Materials, John Wiley \& Sons, Hoboken, NJ, 2006.

[23] ACI 318-14. Building code requirements for structural concrete (ACI 318-14) and commentary. American Concrete Institute, Farmington Hills, 2014.

About Author (s):

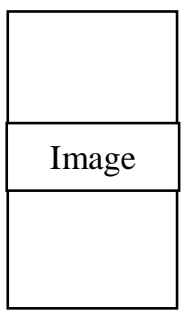

[Test results confirmed that unidirectional carbon FRP sheets can be efficiently used to strengthen circular RC columns and enhance their load-carrying capacity and deformability under eccentric loading.] 